Research Article

www.ijrap.net

\title{
AN OBSERVATION ON THE MERCURY CONTENT ON SCALP HAIR IN THE URBAN COASTAL AREA OF THIRUVALLUR DISTRICT, TAMILNADU, INDIA \\ R. Sumathi, A. Thangamani*
}

Department of Chemistry, Voorhees College Vellore, Tamil Nadu, India

Received on: 08/06/12 Revised on: 23/07/12 Accepted on: 06/09/12

\author{
*Corresponding author \\ Email:pkarthikeyan99@yahoo.com \\ DOI: 10.7897/2277-4343.03527 \\ Published by Moksha Publishing House. Website www.mokshaph.com \\ All rights reserved.
}

\section{ABSTRACT}

This study was carried out to evaluate the mercury content on scalp hair in the urban coastal area of Thiruvallur district, Tamilnadu, India. The average value of total mercury ( $\mathrm{THg}$ ) in scalp hair of male residents living in urban coastal area of thiruvallur district is $8.163 \pm 0.0816 \mathrm{mg} / \mathrm{L}$ and that of female is $0.816 \pm 0.0316$. Values are expressed as the mean SD of 3 individual values. Mercury was found more in the scalp hair of male than female. THg increased with age of subjects in male, but not in female.

Keywords: Total Mercury, scalp hair and standard deviation.

\section{INTRODUCTION}

Hair is a useful indicator of mercury exposure. In the U.S over a million hair samples have been examined for mercury (mean, $1.5 \mathrm{mg} / \mathrm{kg}$ ). In this study we have seen the mercury exposure is higher in the fishermen hair, i.e., the people living in coastal areas. Individuals consuming 4 or more meals of fish per week had hair mercury of 4.01 $\mathrm{mg} / \mathrm{kg}$ day weight of hair while those consuming fish less frequently has significantly lower levels $(2.56 \mathrm{mg} / \mathrm{kg})$. The $\mathrm{Hg}$ level of the body was usually determined by analysis of mercury in blood and scalp hair ${ }^{3,8,9}$. Scalp hair has several characteristics as an ideal tissue for epidemiological study so that it is painlessly removed, even normally discarded and easily corrected. Since trace elements have been measured in hair, these trace elements might be recommended as a practical dosimeter for metallic environmental pollutants ${ }^{2,9,10,11}$. This observation study would provide a useful background for establishing a practical indicator for the determination of the mercury contamination on the coastal area.

\section{MATERIALS AND METHODS Materials}

Hair samples (1-2 gm) were collected at five points of scalp from each person who was exposed to mercury. Hair analyze of the samples were collected from 40 individual living in coastal area Pazaverkadu of Thiruvallur District, Tamilnadu, India was carried out.

\section{Analysis}

About $0.250 \mathrm{gm}$ of dried hair sample taken in a $50 \mathrm{ml}$ beaker was washed and dried. Then it was digested with $10 \mathrm{ml}$ of $6: 1$ mixture of concentration $\mathrm{HNO}_{3}$ and $\mathrm{HClO}_{4}$ and kept overnight at room temperature. The contents in the beaker were heated on a hot plate at $160-180^{\circ} \mathrm{C}$ to obtain white crystalline residue.

It was then diluted with $0.1 \mathrm{~N} \mathrm{HNO}_{3}$, and made up to 100 $\mathrm{ml}$ and analyzed for metal mercury by atomic absorption spectroscopy (Varian, 240). The whole analysis was conducted in clean air room of class 10,000.

\section{RESULTS AND DISCUSSION}

Contents of $\mathrm{THg}$ in the scalp hair of residents in Thiruvallur District, coastal area are summarized below (Table 1 and 2):

Table 1: Mercury Level in Scalp Hair of Thiruvallur Coastal A
Residents
\begin{tabular}{|c|c|c|}
\hline \multirow{2}{*}{ Age } & Mercury mg/l \\
\cline { 2 - 3 } & Male & Female \\
\hline $21-60$ & $8.168 \pm 0.0816$ & $0.816 \pm 0.0316$ \\
\hline \multirow{3}{*}{ Table 2: Mercury Level as Function of Hair Color } \\
\hline Color & \multicolumn{2}{|c|}{ Mercury mg/l } \\
\cline { 2 - 3 } & Male & Female \\
\hline Black & $3.36 \pm 0.1733$ & $1.4465 \pm 0.433$ \\
\hline Mixed & $8.3875 \pm 0.06995$ & $0.8265 \pm 0.055$ \\
\hline White & $12.55 \pm 0.0133$ & $1.274 \pm 0.66$ \\
\hline
\end{tabular}

The average value of $\mathrm{Hg}$ concentrations in scalp hair of male was found to be $8.168 \pm 0.0816 \mathrm{mg} / \mathrm{L}$ and that of female are $0.816 \pm 0.0316 \mathrm{mg} / \mathrm{L}$. Values were expressed as mean SD of 3 individual values. Mercury was found more in the scalp hair of male than female. Mercury concentrations increased with age of subjects in male, and there was no difference among the age groups of female. This trend is in agreement with the previous studies ${ }^{3}$. These results show that the $\mathrm{Hg}$ concentrations in hair samples reflect the difference in life style and food consumption. Fish has been known as an important source of mercury exposure to fish- consuming population groups such as Japanese and Swedish as well as Korean ${ }^{1-}$ 4,11 .

The differences are believed to be due to diet and living environment when compared with other data scalp hair $\mathrm{Hg}$ levels measures $(0.0800 \mathrm{mg})$ in male and female (0.09ppm). Hg level for Tokyo residents in Japan male (2$98 \mathrm{ppm})$ and female $(2.02 \mathrm{ppm})^{7}$ and for Chinese, Malays and Indian residing in Singapore ${ }^{2} 6.1,5.2$ and 5.4 ppm respectively.

Their contents of $\mathrm{Hg}$ in scalp hair may be different according to food sources. In Japan, $\mathrm{Hg}$ levels in hair 


\section{A. Thangamani et al / IJRAP 3(5), Sep - Oct 2012}

samples were quite high. Fish and shell fish, caught in seas uncontaminated by human activity, appeared to be major source of the high level of hair $\mathrm{Hg}$ in Japanese Female subjects ${ }^{5,6}$.

Mercury levels were particularly high in fishermen and in fish from lakes, rivers and coastal water polluted with $\mathrm{Hg}^{4}$. Mercury influenced genetically determined factors ${ }^{10}$ and affects the molecular structure of binding substances. Nutrition and other heavy metals are also important in $\mathrm{Hg}$ toxicity. In the case of fishermen, the increase in hair levels of $\mathrm{Hg}$ concentration was roughly proportional to the dietary intake of fish in both male (husbands) and female (wives). However, husbands were found do have higher hair $\mathrm{Hg}$ levels then wives.

National Research Council in 2000 recommended a lower limit value $(3.4 \mu \mathrm{g} / \mathrm{I})$ for women in reproductive age because of an increased risk of neurotoxin effects on the fetus in case of potential pregnancy. In the period 19962003, a total of 52 women had blood mercury level in excess of $3.4 \mu \mathrm{g} / \mathrm{I}$; however, not all of them were in reproductive age.

The reference value in blood (the higher bound of CI .95 ${ }^{\text {th }}$ percentiles) established for the period 2001 -2003 was $3.45 \mu \mathrm{g} / \mathrm{I}$ for the total adults ${ }^{12}$.

\section{CONCLUSION}

In conclusion, $\mathrm{Hg}$ levels in scalp hair have been found much more in scalp hair of male than that of female. These statements coincide with the research work done in the urban residents of South Korea. Hg levels in scalp hair of fishermen were higher than other non-occupational countries in Asia zone.

\section{REFERENCES}

1. Dickman MD, Leung CK, Leong MK. Hong Kong male sub fertility links to mercury in human hair and fish. Sci. Total Environ. 1998;214: 165-174. http://dx.doi.org/10.1016/S0048-9697(98)00062-X

2. Foo SC, Ngim CA, Ohoon WO, Lee MK. Mercury n scalp hair of healthy Singapore residents. Sci. Total Environ. 1988;721: 113-122. http://dx.doi.org/10.1016/0048-9697(88)90010-1

3. Harada Mortada, W Nakanishi, J Konuma, S Ohno, K Yamaguchi, H Tsuruta, K Kizaki, T Ookawara, T Ohno H. The present mercury contents of scalp hair and clinical symptoms in inhabitants of the Minamata area. Environ. Res. 1988;77: 160 -164.

4. Lee WC, Lee MJ. Mercury concentrations in scalp hair as an environmental contamination index from foods I Korea. Vet. Hum. Toxicol. 1999;41: 373 -375. PMid:10592943

5. Mahaffey KR. Methyl mercury: a new look at the risks. Public Health Rep. 1999;114: 396-399. PMid:10590759 PMCid:1308510

6. Mahaffey KR, Mergler D. Blood levels of total and organic mercury in residents of the upper St. Lawrence $r$ river basin, Quebec: association with age, gender and fish consumption. Environ. Res. 1998;77: 104-114. $\quad$ http://dx.doi.org/10.1006/enrs.1998.3834 PMid:9600803

7. Nakagwa R. Concentration of mercury in hair of Japanese people. Chemosphere 1995;30: 127- 133. http://dx.doi.org/10.1016/00456535(94)00382-5

8. Renzoni A, Zino F, Franchi F. Mercury levels along the food chain and risk for exposed population. Environment. Res. 1998;77: 68-72. http://dx.doi.org/10.1006/enrs.1998.3832 PMid:9600797

9. Sumino K. Scalp hair and mercury Clin. Diagn Japan 1980;24: $767-$ 769.

10. Wakisaka L, Yanagihashi T, Sato M, Nakani A. Factors contributing to the difference of hair mercury concentrations between the sexes. Nippon Eiseigaku Zasshi 1990;45: 654-664. http://dx.doi.org/10.1265/jih.45.654

11. Airey D. Total mercury concentration in human hair from 13 countries in relation to fish consumption and location. Sci. Total Environ. 1983;31: 157-180. http://dx.doi.org/10.1016/0048-9697(83)90067-0

12. Bacoriavo. Hair trace element analysis in human ecology studies. Toxicology 2006: 101: 29.

\section{Cite this article as:}

R. Sumathi, A. Thangamani. An observation on the Mercury content on scalp hair in the urban coastal area of Thiruvallur district, Tamilnadu, India. Int. J. Res. Ayur. Pharm. 2012; 3(5):715-716 